\title{
LIVING LABS - INNOVATE BUSINESS MODELS FOR RURAL REGIONS
}

Heidelinde GRÜNEIS, Federal Institute of Agricultural Economics, Rural and Mountain Research, Marxergasse 2, 1030 Vienna, Austria heidelinde.grueneis@ bab.gv.at (corresponding author)

Sigrid EGARTNER, Federal Institute of Agricultural Economics, Rural and Mountain Research, Marxergasse 2, 1030 Vienna, Austria, sigrid.egartner@bab.gv.at

Julia NIEDERMAYR, Federal Institute of Agricultural Economics, Rural and Mountain Research, Marxergasse 2, 1030 Vienna, Austria, julia.niedermayr@bab.gv.at

Karin HEINSCHINK, Federal Institute of Agricultural Economics, Rural and Mountain Research, Marxergasse 2, 1030 Vienna, Austria, karin.heinschink@bab.gv.at

Klaus WAGNER, Federal Institute of Agricultural Economics, Rural and Mountain Research, Marxergasse 2, 1030 Vienna, Austria, klaus.wagner@bab.gv.at

Rural regions are confronted with several challenges, such as depopulation, overageing or a declining economic importance of the primary sector. Thus, innovative efforts are required to make such regions more attractive and to maintain and further develop social and physical infrastructure. HORIZON 2020 project LIVERUR aims at strengthening rural regions by expanding innovative business models set up as Living Labs, which are user-centred and open-innovation ecosystems. Living Labs establish a sustainable stakeholder partnership, where users, policy-makers, companies and researchers engage in a long-term collaboration. Within LIVERUR, suitable rural business models are identified and will be developed towards the Living Lab concept. Therefore, a framework with a criteria system with the most relevant LIVERUR topics was developed, following a literature review on important documents of the United Nations and EU as well as scientific publications. This criteria system focuses on four main criteria: 1. Living Lab approach, 2. Economic sustainability, 3. Social sustainability and 4. Ecological sustainability. Each criterion is supplemented with 3 to 6 concrete indicators, which help to create a comprehensive view on sustainable business models linked to the Living Lab approach. The results show 20 business models within 13 pilot regions, which are largely on a high level of development, but most of them still have potential for further development. The presented framework is easy in its application and helps to assess and illustrate business models regarding Living Lab and sustainability characteristics. It is also helpful to highlight a business model's potential for development.

Keywords: Business models, Living Labs, Rural Development

\section{INTRODUCTION}

Rural regions have been undergoing significant changes over the last decades, such as demographic changes, migration trends or agricultural intensification. One of the greatest current challenges is the strong depopulation trend within EU rural regions, which is underpinned by low birth rates, out-migration of younger qualified people and ageing of the population (Perpiña 2018). The urban-rural gap is likely to further increase within the next few years and therefore calls for action. Apart from that, rural regions perform a multitude of key environmental, economic, social and cultural functions, such as living, economy, nature protection, recreation, tourism or food production (Penke 2012). These multiple challenges call for new and innovative solutions that strengthen rural regions and create sustainable added-value, jobs, and resilience in general. Agriculture is especially linked to rural regions and integrates food production, rural development, and natural resources management (EEA 2011, Iglesias 2012). Next to general rural challenges, agriculture is challenged with many economic and social aspects, which are gradually intensified by climate change (Ciscar et al. 2009; Schröter et al. 2005). Furthermore, the economic importance of the primary sector is declining in rural areas (Douwe and Roep 2003, ESPON 2018). Thus, innovative approaches based on the goals of sustainable development are particularly needed for the agricultural sector. Overall, rural structures have to be strengthened to maintain and further develop social and physical infrastructure and to improve quality of life for rural citizens and keep rural regions attractive places to live.

Within the EU HORIZON 2020 programme, LIVERUR ("Living lab research concept in rural areas") aims to expand innovative business models called "Living Labs" among rural regions with a special focus on the agricultural sector. The Living Lab concept will be applied for SMAEs (Small - Medium Agricultural Enterprises) to create added value and business resilience facing current challenges (LIVERUR 2018). The European network of Living Labs (ENoLL) defines a Living Lab as "an open innovation environment in real-life settings in which user-driven innovation is the co-creation process for new services, products and societal infrastructures. Living Labs encompass societal and technological dimensions simultaneously in a business-citizens-government-academia partnership" (Bergvall-Kareborn

Copyright $\odot 2019$ The Authors. Published by Vytautas Magnus University. This is an open-access article distributed under the terms of the Creative Commons Attribution License (CC-BY 4.0), which permits unrestricted use, distribution, and reproduction in any medium, provided the original author and source are credited. 
and Stahlbröst 2009). The essence of the user-driven approach is the direct involvement of users in the development processes of products and services. This human-centric approach considers humans as the source of innovation, not just as an object for testing and feedback (Schaffers et al. 2007). LIVERUR aims to apply the Living Lab concept in rural areas and improve knowledge of business models growing in rural regions and enhance the understanding of their potential (Liverur 2018).

Besides, two already existing concepts will be merged into one business model: the Living Lab approach and the Circular Economy. These approaches will be applied in 13 rural project pilot regions in 11 countries (AT, CZ, ES, MT, PT, SI, FR, LV, TR, IT, TN). One further step will be to develop a concept for a regional circular Living Lab Approach in rural areas, called RAIN model.

The following article aims at presenting a framework that enables to categorise business models regarding Living Lab- and sustainability characteristics. We developed a criteria system based on an extensive literature review as well as a graphical presentation for business models that help to show strengths and weaknesses and therefore also potential for development. In the following section, we describe the methods used and present the criteria system for assessing sustainable rural business models. Based on these criteria, we illustrate the application with an example of a project from Southern Burgenland (Austria). Finally, we end with a discussion of our results and conclusions.

Development of an indicator system for characterising sustainable rural business models

Within a first step, important topics from the LIVERUR project were collected (see Figure 1) and then narrowed by a criteria and indicator system for its practical applicability. Due to Marker (2011) a criteria and indicator system should be specific, measurable, applicable, sensitive, available and cost-efficient. The new system should cover all relevant topics, but avoid overlapping and double evaluation. As a great number of various criteria already exists, it is not necessary to develop new indicators, but to identify the most appropriate ones for the LIVERUR project purpose.

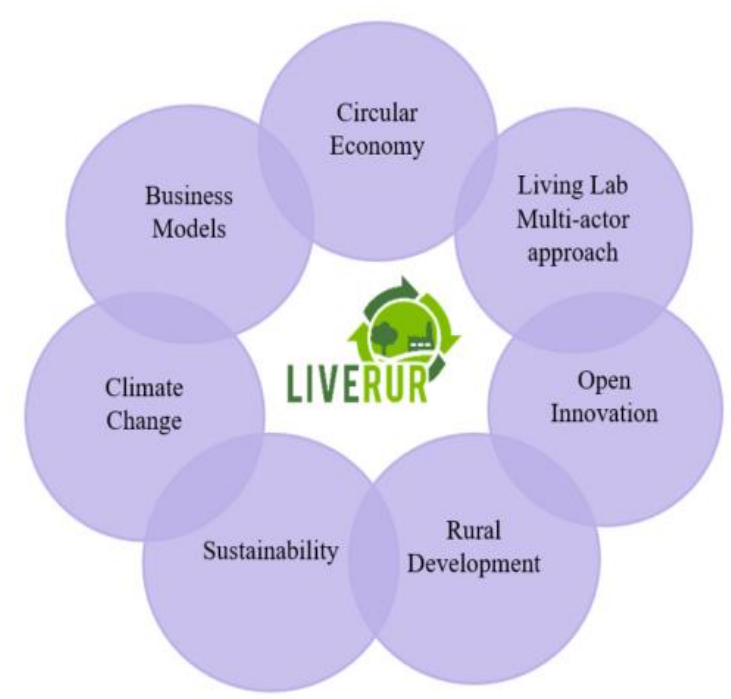

Figure 1. LIVERUR concepts (LIVERUR 2019)

A literature review was conducted for an identification of relevant criteria that help classify already existing business models and show their potential for development. The literature research included resolutions, policy papers, guidelines and recommendations from the United Nations (e.g. Sustainable Development Indicators), OECD (e.g. Agri-Environmental Indicators) and the EU (e.g. Regional Innovation Scoreboard, Monitoring and Evaluation Framework, EIP AGRI common format, Assessment of Research and Innovation on Food Systems, Eco-innovation Action Plan) as well as scientific publications on the relevant topics. Within a next step, a basic set of qualitative criteria with 4 main topics (criteria) was developed and supplemented with 3 to 6 indicators each (see Table 1). Project partners filled in a table where 3 answer options were provided for each question (indicator) (e.g. 2.1 "Are the users engaged in the process of innovation" 1. "no users involved", 2. "users partly involved, 3. "users involved during the whole process").

\section{Application of sustainable business model indicators - one example}

Within the following chapter, we show the application of our framework, using one example from Austria. This example was selected randomly and is not representative for all other LIVERUR business models. This example was chosen, because we have good access to relevant data and cooperate closely with project partners from the study region Southern Burgenland.

In Austria, the association Southern Burgenland - "A piece of paradise®" - has been established 14 years ago. The main goal from the very beginning was and still is to make the companies of Southern Burgenland, in particular producers, direct markets, farmers, leisure facilities and hotels, accessible to the general public. The paradise family consists of about 50 companies from different areas who work together on increasing awareness and developing the "paradise region Southern Burgenland" (Liverur 2019). This well-established business model was analysed according to the above presented criteria and illustrated in the following radar chart (Figure 2). 
Table 1: Criteria and indicators for classification of LIVERUR sustainable rural business models (LIVERUR 2019)

\begin{tabular}{|l|l|l|}
\hline \multicolumn{1}{|c|}{ Criteria and Indicators } & \multicolumn{1}{|c|}{ Descriptive Question } & \multicolumn{1}{|c|}{ References } \\
\hline 1. LIVING LAB APPROACH & \multicolumn{1}{|c|}{$\begin{array}{l}\text { Are the users engaged in the process of } \\
\text { innovation? }\end{array}$} & $\begin{array}{l}\text { Bergvall-Kareborn and } \\
\text { Stahlbröst (2009); Steen and van } \\
\text { Bueren (2017) }\end{array}$ \\
\hline 1.1 User-centered & $\begin{array}{l}\text { Are relevant stakeholders (e.g. from government, } \\
\text { academia, citizens, business) involved in the } \\
\text { process? }\end{array}$ & $\begin{array}{l}\text { Bergvall-Kareborn and } \\
\text { Stahlbröst (2009); Steen and van } \\
\text { Bueren (2017) }\end{array}$ \\
\hline $\begin{array}{l}\text { 1.3 Level of } \\
\text { engagement/participation }\end{array}$ & $\begin{array}{l}\text { In which form does the co-creation with } \\
\text { stakeholders (incl. users and policymakers) take } \\
\text { place? }\end{array}$ & $\begin{array}{l}\text { Arnstein (1969); Steen and van } \\
\text { Bueren (2017) }\end{array}$ \\
\hline 1.4 Openness & $\begin{array}{l}\text { Are the activities open for new partners, users, } \\
\text { investors, etc. during the whole process? }\end{array}$ & Chesbrough (2006) \\
\hline 1.5 Real-life setting & $\begin{array}{l}\text { Do the activities take place in the real-life use } \\
\text { context? }\end{array}$ & $\begin{array}{l}\text { Bergvall-Kareborn and } \\
\text { Stahlbröst (2009); Steen and van } \\
\text { Bueren (2017) }\end{array}$ \\
\hline 1.6 Technological integration & $\begin{array}{l}\text { Do the activities foster new technological } \\
\text { developments? }\end{array}$ & Liedtke et al. (2012) \\
\hline
\end{tabular}

\section{ECONOMIC SUSTAINABILITY}

\begin{tabular}{|l|l|l|}
\hline 2.1. Innovation/type of innovation & $\begin{array}{l}\text { Which type of innovation do the activities } \\
\text { follow? }\end{array}$ & $\begin{array}{l}\text { Bergvall-Kareborn and } \\
\text { Stahlbröst (2009); SDG } 9\end{array}$ \\
\hline 2.2 Regional conditions & $\begin{array}{l}\text { How do the activities consider regional } \\
\text { conditions? }\end{array}$ & $\begin{array}{l}\text { European Commission (2015); } \\
\text { ENRD (2018) }\end{array}$ \\
\hline $\begin{array}{l}\text { 2.3 Resources (financial, } \\
\text { infrastructure, manpower, } \\
\text { technological) }\end{array}$ & $\begin{array}{l}\text { Are the resources secured within the next 12 } \\
\text { months? }\end{array}$ & Osterwalder and Pigneur (2010) \\
\hline
\end{tabular}

\begin{tabular}{|l|l|l|}
\hline 3. SOCIAL SUSTAINABILITY \\
\hline 3.1 Health and wellbeing & $\begin{array}{l}\text { Do the activities foster healthy lives and promote } \\
\text { well-being? }\end{array}$ & UNDP (2017) SDG 3 \\
\hline 3.2 Quality education and learning & $\begin{array}{l}\text { Do the activities foster inclusive and equitable } \\
\text { quality education and promote lifelong learning } \\
\text { opportunities? }\end{array}$ & UNDP (2017) SDG 4 \\
\hline 3.3 Culture & $\begin{array}{l}\text { Do the activities consider cultural aspects and } \\
\text { foster cultural development? }\end{array}$ & $\begin{array}{l}\text { Agenda 21 for culture (2017); } \\
\text { Soini and Birkland (2014) }\end{array}$ \\
\hline 3.4 Social equity & $\begin{array}{l}\text { Do the activities achieve gender equality and } \\
\text { other forms of social equity? }\end{array}$ & $\begin{array}{l}\text { UNDP (2017) SDG 5, SDG 10, } \\
\text { Sen(2000) }\end{array}$ \\
\hline
\end{tabular}

\begin{tabular}{|l|l|l|}
\hline 4. ECOLOGICAL SUSTAINABILITY \\
\hline 4.1 Climate action and biodiversity & $\begin{array}{l}\text { Do the activities take urgent action to combat } \\
\text { climate change and its impacts and take action to } \\
\text { foster biodiversity? }\end{array}$ & UNDP (2017) SDG 13; SDG 15 \\
\hline $\begin{array}{l}\text { 4.2 Resource management and } \\
\text { energy from renewable resources }\end{array}$ & $\begin{array}{l}\text { Do the activities ensure sustainable management } \\
\text { and use energy from renewable resources (e.g. } \\
\text { certification)? }\end{array}$ & $\begin{array}{l}\text { EMF (2015); Lewandowski } \\
\text { (2016); UNDP (2017) SDG 6; } \\
\text { SDG 7; SDG 14; SDG 15 }\end{array}$ \\
\hline 4.3 Products/material regeneration & $\begin{array}{l}\text { Are the products designed for reuse and/or is } \\
\text { there support during the whole product life-cycle } \\
\text { in the sense of a circular economy? }\end{array}$ & $\begin{array}{l}\text { EMF (2015); } \\
\text { Lewandowski (2016) }\end{array}$ \\
\hline $\begin{array}{l}\text { 4.4 Responsible production and } \\
\text { consumption }\end{array}$ & $\begin{array}{l}\text { Do the activities focus on responsible } \\
\text { consumption and production patterns? }\end{array}$ & $\begin{array}{l}\text { EMF (2015); UNDP (2017) } \\
\text { SDG 12 }\end{array}$ \\
\hline
\end{tabular}




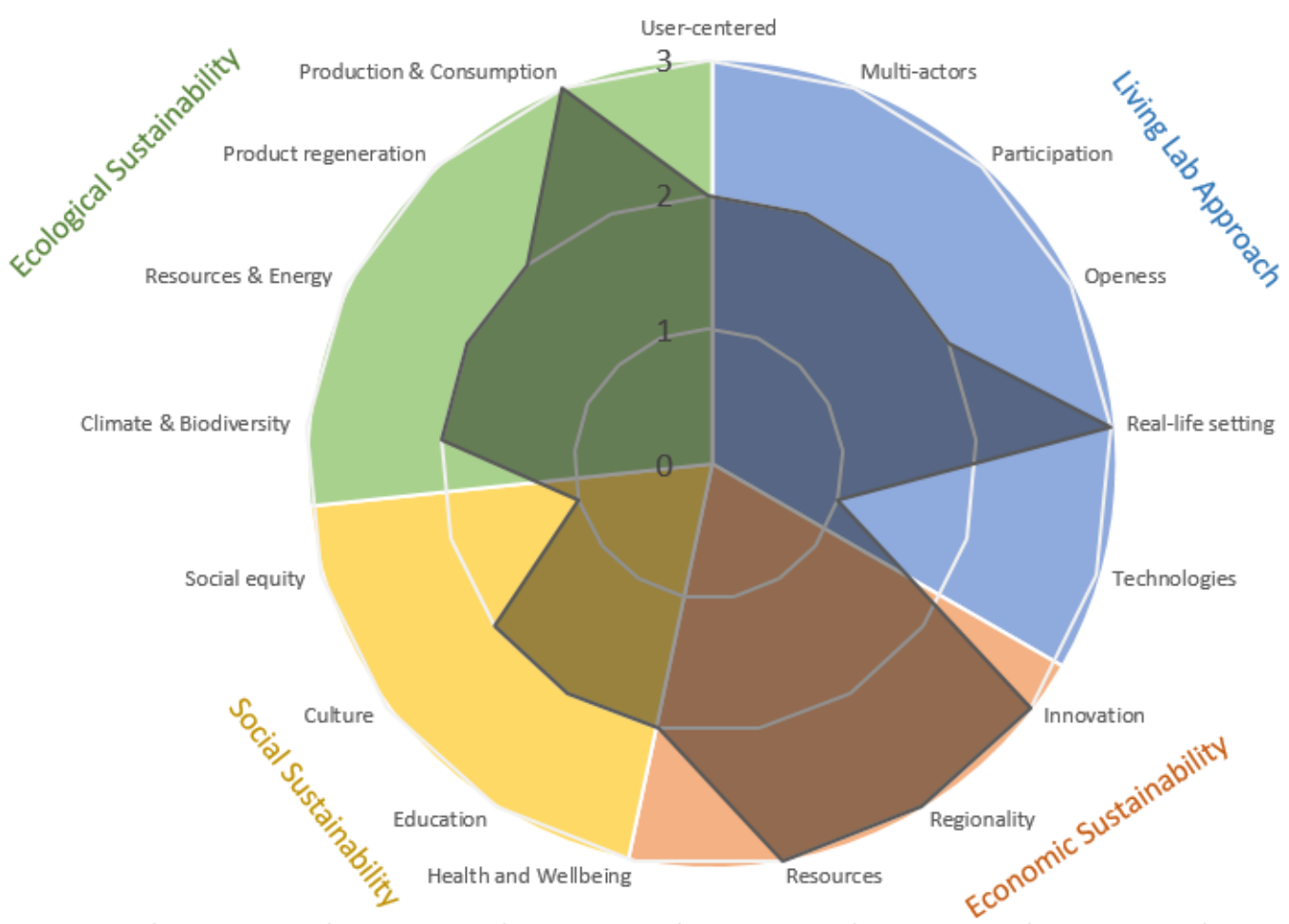

Figure 2 Characterisation of a Living Lab, Example: “A piece of paradise” Southern Burgenland (Austria) NOTE for Editor: New graph inserted

"A piece of paradise" shows its strengths especially in the field of economic sustainability. Although already on a very high level, potential for further development can mainly be seen towards social sustainability, but also towards the Living Lab approach. In a pilot region workshop with stakeholders it turned out that there is a vision of a Living Lab Southern Burgenland (LLSB), which supports food sovereignty for certain products in the region by stimulating product and service innovations. LLSB wants to achieve this ambitious goal by using available resources more innovatively and more efficiently and by promoting the principle of circularity in the local business cycle. More specifically, LLSB's goals shall be met by various initiatives like innovative use of fallow land, new forms of (technologically supported) regional goods distribution and use of existing potentials for example in fruit production, processing and marketing. Awareness of regional resources, regional production, regional cycles as well as awareness of the relevance of food sovereignty and landscape amenities should be strengthened among potential consumers (Liverur 2019).

\section{Selected rural business models within LIVERUR}

LIVERUR project region partners provided data for altogether 39 projects/business models. After an analysis and feedback phase, 20 business models were selected for further development within LIVERUR project. The projects are at very different stages of their development: from ideas to well-established businesses. The conceptual orientations of the business models from altogether 11 different countries are also very diverse. Although there is a strong focus on the agricultural sector, the thematic diversity is very high, e.g. energetic transition, biowaste, regional food marketing, biogas production, waste reduction, etc. A common feature is the establishment of networks, collaborations and involvement of stakeholders, which are some of the main ideas of a Living Lab.

\section{CONCLUSIONS AND DISCUSSION}

The presented framework allows for a qualitative assessment of business models regarding Living Lab and sustainability characteristics. We applied this framework to different business models in 13 rural project pilot regions in 11 countries within EU HORIZON 2020 programme LIVERUR. Within this paper, we presented the framework using one example from Austria. Within our framework, radar charts visualize the potential for further development of individual business models and may also be used for a comparison of different business models.

The strengths of our framework are clearness, transparency and flexibility: The framework provides a straightforward and concise overview of the observed business models' status regarding sustainability and Living Lab characteristics. Criteria and indicators can be modified, added or removed. Depending on data quality, different layers of analysis are possible, such as: periods of time (e.g. status quo, expected status in 5 years); economic activities (e.g. agriculture, forestry, tourism); regions (e.g. EU, regional, local). A large amount of information can be arranged clearly by juxtaposing multiple radar charts. The results are organised in an easily understandable way and can be presented to an audience with no, or little previous knowledge.

Apart from these strengths, certain limitations need to be considered. For instance, it is very important to provide clear questions for indicators as well as clear answers which can easily be understood by those who collect the data. If 
questions/answers leave too much room for interpretation, results cannot be analysed and/or compared meaningfully. Thus, the framework is hardly suitable for more complex questions. Another limitation lies in the visualization of more criteria than our example shows, the number of criteria and indicators included in the radar charts should be limited for clarity. For the visualisation of more criteria or indicators, it is recommended to use another type of graphic presentation.

The presented approach was applied in the LIVERUR project (LIVERUR 2018, 2019) in order to select business models for each region for further development within the project. The data was collected by regional interviewers with an advanced knowledge of the region and good contacts to project partners. On the one hand, this means that comparability across regions is very limited. On the other hand, the project seeks to identify regional characteristics, not comparability across regions. Hence, intraregional assessment was considered more useful in this particular application. The framework proved as easily comprehensible and uncomplicated in its practical application with different project partners.

\section{REFERENCES}

1. Arnstein S. 1969. A ladder of citizen participation. Journal of the American Institute for Planners 35, pp.216-244. https://doi.org/10.1080/01944366908977225

2. Bergvall-Karebornd B., Stahlbröst A. 2009. Living Lab: an open and citizen-centric approach for innovation. International Journal of Innovation and Regional Development 4, pp. 356-370. https://doi.org/10.1504/IJIRD.2009.022727

3. Chesbrough H. 2006. Open Innovation. The new imperative for creating and profiting from technology. Harvard Business Review Press, Boston.

4. Ciscar J.C., Iglesias A., Feyen L., Goodess C.M., Szabó L., Christensen O.B., Nicholls R., Amelung B., Watkiss P., Bosello F., Dankers R., Garrote L., Hunt A., Horrocks L., Moneo M., Moreno A., Pye S., Quiroga S., Van Regemorter D., Richards J., Rososn R., Soria A. 2009. Climate change impacts in Europe. Final report of the PESETA research project. EUR 24093 EN. JRC Scientific and Technical Reports. Available at http://ftp.jrc.es/EURdoc/JRC55391.pdf (accessed on 06/06/2019)

5. Douwe J., Roep D. 2003. Multifunctionality and rural development: the actual situation in Europe. In: Huylenbroeack, G.and Durand, G. 2003. Multifunctional Agriculture; A new paradigm for European Agriculture and Rural Development. Ashgate, Hampshire, pp.37-53.

6. European Commission 2015. Closing the loop - An EU action plan for the circular economy. EC, Brussels.

7. EEA (European Environment Agency) 2011. Agriculture. Available at https://www.eea.europa.eu/themes/agriculture/intro (accessed on 06/06/2019)

8. EMF (Ellen MacArthur Foundation) 2015. Towards a circular economy: business rationale for an accelerated transition. Ellen MacArthur Foundation.

9. ENRD (European Network for Rural Development) 2018. EU Rural Review 26 `Smart Villages: Revitalising Rural Services`. Available at https://enrd.ec.europa.eu/publications/eu-rural-review-26-smart-villages-revitalising-rural-services_en (accessed on 01/03/2019)

10. ESPON 2018. Small and Medium-sizes enterprises in European regions and cities. Available at https://www.espon.eu/sites/default/files/attachments/SME_final-report_MainReport_20.pdf (accessed on 06/06/2019)

11. Lewandowski M. 2016. Designing the business models for circular economy - Towards the conceptual framework. Sustainability, Vol. 8(1), Id.43, pp. 1-28.

12. Liedtke C., Welfens M.J., Rohn H., Nordmann J. 2012. Living Lab: User-driven innovation for sustainability. International Journal of Sustainability in Higher Education, Vol. 13, No. 2, pp. 106-118. https://doi.org/10.1108/14676371211211809

13. LIVERUR 2018. Grant Agreement number: 773757. Unpublished internal document.

14. LIVERUR 2019. Deliverable WP 4.1. Unpublished internal document.

15. Marker M. 2011. Nachhaltigkeitsindikatoren aus theoretischer und praktischer Perspektive. Master Thesis. Carl von Ossietzky Universität Oldenburg, Oldenburg.

16. Osterwalder, A. and Pigneur, Y. 2010. Business Model Generation: A Handbook for Visionaries, Game Changers, and Challengers. Wiley, New Jersey.

17. Perpiña C., Kavalov B., Ribeiro Barranco R., Diogo V., Jacobs-Crisioni C., Batista e Silva F., Baranzelli C., Lavalle C. 2018. Territorial Facts and Trends in the EU Rural Areas within 2015-2030, Publications Office of the European Union, Luxembourg.

18. Penke S. 2012. Ländliche Räume und Strukturen - mehr als eine "Restkategorie" mit Defiziten. In: Debiel, S. (Hrsg) Soziale Arbeit in ländlichen Räumen. VS Verlag für Sozialwissenschaften, Springer Fachmedien ,Wiesbaden. https://doi.org/10.1007/978-3-531-18946-8_2

19. Schaffers H., Cordoba M. G., Hongisto P., Kallai T., Merz C., Van Rensburg J. 2007. Exploring business models for open innovation in rural living labs. In: 2007 IEEE International Technology Management Conference (ICE): 1-8. IEEE.

20. Schröter D., Cramer W., Leemans R., Prentice I.C., Araújo M.B., Arnell A.W., Bondeau A., Bugmann H., Carter T., Gracia C.A., de la Vega-Leinert A.C., Erhard M., Ewert F., Glendining M., House J.I., Kankaanpää S., Klein R.J.T., Lavorel S., Lindner M., Metzger M., Meyer J., Mitchell T.D., Reginster I., Rounsevell M., Sabate S., Sitch S., Smith B., Smith J., Smith P., Sykes M.T., Thonicke K., Thuiller W., Tuck G., Zähle S., Zierl B. 2005. Ecosystem service supply and vulnerability to global change in Europe. Science, Vol. 310, pp. 1333-1337.

21. Steen K., van Bueren,E. 2017 The defining characteristics of urban living labs. Technology Innovation Management Review, Vol. 7, pp21-33. https://doi.org/10.22215/timreview/1088

22. UNDP (United Nations Development Programme) 2017. Sustainable Development Goals. Available at https://www.undp.org/content/undp/en/home/sustainable-development-goals.html (accessed on 06/06/2019) 